\title{
Securitisation of Migration Revisited: European Union Policies Through the Lens of Syrian Refugees Living in Turkey
}

\author{
Göçün Güvenlikleştirilmesine Yeni Bir Bakış: Türkiye'de Yaşayan Suriyeli Mültecilerin \\ Gözünden Avrupa Birliği Politikaları
}

\author{
Pelin Sönmez ${ }^{1}$, Özgür Ünal Eriş² ${ }^{2}$
}

\begin{abstract}
The main aim of this study is to present migration as a 'constructed' societal insecurity threat that became substantial after the Cold War before peaking in 2015. This study applies securitization theory to the ongoing refugee crisis through in-depth interviews with a sample of Syrian settlers in Turkey to determine whether their reasons for choosing to stay in Turkey are linked to their perceptions of cultural insecurity in Europe. The interviews were made in November and December 2019 in Gaziantep, Antakya and İstanbul where most of the Syrian refugees are located. In that sense, the link between the securitisation theory and the interviews made in Turkey attempts to shed light on the awareness of Syrian refugees regarding the fact that the European Union (EU) has tried to create a culturally homogenous society and any kind of difference interfering in this homogeneity can be seen as a threat.
\end{abstract}

\section{Keywords}

European Union, securitisation of migration, Syrian refugees, speech analysis, populist parties

\section{Öz}

Bu çalışmanın temel amacı Soğuk Savaş sonrasında önem kazanan ve 2015 yılında en yüksek noktasına varmadan önce gündeme gelen göç konusunu "inşa edilmiş" sosyal güvensizlik tehdidi olarak sunmaktır. Çalışma devam etmekte olan mülteci krizinden hareketle, güvenlikleştirme teorisini Türkiye'de yaşamakta olan Suriyeli yerleşimci bir örneklem grup ile derinlemesine mülakatlar yoluyla araştırmış ve bu grubun Türkiye'yi seçme nedenlerinin Avrupa'ya ilişkin kültürel güvensizlik algılarıyla ilgili olup olmadığını tespit etmeye çalışmıştır. Çalışma kapsamında geliştirilen mülakatlar Kasım ve Aralık 2019 tarihlerinde yürütülmüş ve Suriyeli mülteci nüfusunun en yoğun olduğu Gaziantep, Antakya ve İstanbul illerinde gerçekleştirilmiştir. Bu bağlamda güvenlikleştirme teorisi ve Türkiye'de gerçekleştirilen mülakatlar arasındaki bağın, Avrupa Birliği'nin (AB) kültürel manada homojen bir toplum yaratma çabası ve bu homojenliğe müdahale eden her türlü farklılığın bir tehdit olarak görülebilmesi durumunu akılda tutarak, Suriyeli mültecilerdeki bilincin açığa çıkması için bir ışık tutmasına çalışılmıştır.

\section{Anahtar Kelimeler}

Avrupa Birliği, göçün güvenlikleştirilmesi, Suriyeli mülteciler, konuşma analizi, popülist partiler

1 Corresponding Author: Pelin Sönmez (Assoc. Prof. Dr.), Kocaeli University, Faculty of Economics and Administrative Sciences, Department of International Relations, Kocaeli, Turkey. E-mail: pelin.sonmez@kocaeli.edu.tr ORCID: 0000-0002-4899-6826

2 Özgür Ünal Eriş (Prof. Dr.), Istanbul 29 Mayıs University, Faculty of Economics and Administrative Sciences, Department of International Relations, Istanbul, Turkey. E-mail: derinozgur74@gmail.com ORCID: 0000-0003-0947-6761

To cite this article: Sonmez, P., \& Unal Eris, O. (2021). Securitisation of Migration Revisited: European Union Policies Through the Lens of Syrian Refugees Living in Turkey. SiYASAL: Journal of Political Sciences, 30(2), 225-241. http://doi.org/10.26650/siyasal.2021.30.899160 


\section{New security threats: securitization of migration}

After the end of the Cold War the understanding of both security communities and security threats changed, mainly from an exclusive stress on territorial security to a much greater stress on societies 'security. This made concepts like identity and culture even more relevant. States need independence to survive whereas, for societies, survival is determined by identity and culture. Consequently, processes that undermine, disrupt, or weaken a society's identity led to societal insecurity, particularly when a society defines a given change, development, or potentiality as a threat to its survival as a community. An insecure society does not resort to military action; rather, it turns to processes that strengthen and juxtapose 'us' versus 'them'. As a result, issues connected with migration become an important security threat because migrants are considered outsiders to a community that was previously created by shared culture and identity.

The connection between societal security and socio-cultural security was elaborated in detail by pioneers of the Copenhagen School of security, Barry Buzan, Ole Waever, and Jaap de Wilde (1998), in their book 'Security: ANew Framework for Analysis'. They point to identity as the organizing concept in societal security (Buzan, Waever, de Wilde, 1998).That is, societal identity within a security community does not exist peacefully; rather, it has inner tensions and conflicts, which provoke a willingness to defend itself against internal or external threats. This leads to migration and migrant communities being perceived as a security threat to the identity of the receiving state for two reasons (Stivachtis, 2008: 4). First, cultures and norms in a community differ in how they define who belongs to or can be admitted into their community. Because a violation of these norms by a culturally different migrant community is often regarded as threatening basic values, it is perceived as a threat to security. Therefore, the state in question may fail to structure a well-functioning integration policy because its society is reluctant to take refugees for a long-term stay. Second, the question of how and why some migrant communities are perceived as threats to the identity of the receiving state also involves how migrants decide to deal with the host community (Stivachtis, 2008: 4). Some groups of migrants who do not seek to integrate reject the rules, norms, and laws of the society they live in. They may become deviant with high crime rates, live in closed ethnic neighborhoods, and if they are Muslim, call for the use of Sharia law in Europe and wearing of the hijab, which conflicts with European values (Johnson, 2011).Thus we can say that the failure for a successful integration policy may be the result of attitudes of both sides; the receiving state and society and the refugees.

While the boundary between 'them' and 'us' may change, the division is necessary to preserve the society's identity. From the society’s viewpoint, especially Muslim migrants are different. This religiously and culturally different group has constituted the main 'other' in Europe's past. European identity was not formed by Islam but predominantly by the relationship to Islam (Bartoszewicz, 2015: 38). From that relationship, Europe has developed a 'collective identity' ${ }^{1}$ and the ability to orchestrate action within a security community. As migrants become more visible and more substantial in numbers, the homogenous security community that was meant to be created by the EU becomes more

1 Jacques Derrida evaluates collective identity in terms of forming 'them' before 'us'. According to this argument, differentiation determines collective identity while the social bond as a unifying factor can only be constructed by defining an outer space (Derrida, 1992). 
vulnerable to cracks and malfunctions. Thus, a security threat to the EU could lead to the fragmentation of a carefully integrated security community and destroy Europe as a project.

In reality, however, migrants may not reflect an existential threat to the receiving states; instead, particular social groups within them may successfully frame migrants as a 'security problem'. This is the core of the securitization perspective of Buzan, Waever, and de Wilde (1998). They argue that a security complex has three main elements: a reference point (the threatened element that needs to survive), the securitizing actor (the element that presents a topic as a security threat because it supposedly threatens the reference point), and the functional actors (who affect the dynamics of the sector). Jef Huysmans contributes by identifying three kinds of security threat referent objects: internal security, cultural identity, and the welfare state. In the case of internal security, the core is the internal market and, as a corollary, the free movement of people. Cultural identity and the welfare state become more relevant as referent objects in the securitization of migration. In addition to seeing migration and migrants as security threats to the collective identity of their security community, the citizens of the host country do not want to share the social and economic rights of the welfare state with migrants. They see migrants as freeriding from welfare state benefits and therefore harming it. This provokes welfare chauvinism whereby migrants are seen as threatening both the host society's cultural homogeneity and its welfare state (Huysmans, 2006: 78; Buzan, Weaver and de Wilde,1998: 46-47).

The securitizing actor, the power holder, may use securitization to gain control over any issue; hence, securitization can be based not only on a real existential threat but also on a perceived threat (Waever, 1995: 54). Thus, declaring something to be a security issue becomes a political choice (Weaver, 1995: 65). For Weaver and his colleagues, there are no security issues but 'securitized' issues; that is, socially constructed phenomena through securitizing speech acts. State representatives usually say in their speeches that security is about survival. If there is an existential threat against a designated referent object, there is also a security matter for which extraordinary measures are needed (Buzan, Waever and de Wilde, 1998: 21-24). This is accepted as such by the 'audience' of the speech act, the electorate.

Societal insecurity triggered by migration manifests itself in the political radicalization of societies. This is evidenced by the rising popularity of anti-establishment (populist) parties as societies start voting for political forces that securitize migration and even use nationalism, xenophobia, and racism in their speech acts (Huysmans, 1995: 72-73).

However, the fact that securitisation theory links the concepts of cultural and societal security to growing racist tendencies among some politicians and political parties has also led to its criticism. Among the prominent critics to this theory, we can cite Alison Howell and Melanie Richter-Montpetit's(2020) article published in the Journal titled Security Dialogue. They are particularly critical of securitisation theory's focus on white Western superiority that privileges Europe as the apex of civilization and the fact that must be protected from (excessive) securitization with a risk of 'regression' to a lower level of civilization or a fully uncivilized 'state of nature'. For them, securitization theory's racism is also evident in its methodology, which examines securitizing speech acts to defend this (European, civilized) 'normal politics'.(Howell and Richter-Montpetit, 2020: 12-14) 
Apart from criticisms to the Copenhagen school of securitisation there are two more schools: Welsh School of Critical Security Studies and Paris School of Security Studies. .

Welsh School of critical security studies was promoted by scholars such as Ken Booth, Richard Wyn Jones and Andrew Linklater based at the University of Wales, Aberystwyth. Welsh school scholars reject the statism and scientism of the traditional studies and furthermore they reconceptualize the security studies. By paying attention to Individual human beings, ethnic groups, nations, and the whole global community of humankind they focus on the alternative actors of the security issues Even though international structure is presented as an anarchical order, critical scholars believe that security and cooperation is possible though actors other than the state itself . (Booth, 1999, 5-6; 2004: 260) This complex nature of the security also promotes the inclusion of the other threats in addition to the military oriented threats. In that sense it can be said to have common points with Copenhagen school of securitisation because it also treats migration as a security threat; but it is far from analyzing speeches of politicians and their perceptions which is in fact the main issue of analysis in this article.

Another school of security studies that similarly tries to integrate other disciplines in the study of security and conflict is the Paris School, with Didier Bigo as its most prominent representative. The Paris School aims to analyze security issues by using conceptual and operational tools from the realms of international relations, sociology, and criminology. It continues the Copenhagen School of securitisation and adds to the analysis of securitization processes based on speech acts and on the significance of security practices with the help of sociological approaches (Langwald, 2021).

The Paris School also reanalyzes the role of the state arguing that nowadays the state does not have the same authority as before. The Paris School focuses on the newly emerged transnational network of security professionals; professionals or experts of security. Bigo claims that this field follows specific rules of the game that presupposes a particular mode of socialization or habitus on the parts of these professionals. The habitus also plays a central role in shaping securitization processes but is not strongly defined along the lines of national borders(Bigo, 2002)

\section{Securitization of Migration in European Politics}

When societal security concerns escalate to the point of securitization, migration becomes the fulcrum of the political agenda. Migration, particularly irregular migration, has always been an important - but not the most important - problem on the political agendas of European leaders, at both national and EU level. The situation changed dramatically in 2015when nearly two million migrants arrived at Europe. When the Chancellor of Germany, Angela Merkel, pledged to provide refuge to anyone seeking protection from violence and war $\mathrm{abroad}^{2}$ and the number of refugee applicationspeaked, the outcome was the decreasing number of votes for her party Christian Democratic Union (CDU) and the increasing number of votes for the radical right party Alternative

2 Although Merkel had been somewhat critical of refugees after 2011, she changed her policy in 2015, when she used a motivational slogan for opening Germany's doors to refugees by saying "Wirschaffen das'- meaning 'We can do it'. She used it by justifying that Germany is a major power to support refugees economically, as well as having the capacity to protect and maintain European heritage politically by remaining loyal to universal human rights. 
für Deutschland (AfD) in the 2017 election. The AfD entered the national parliament with $12.6 \%$ of the vote in the 2017 election to become the third largest party. Opposition to Merkel's refugee policies kept the party together and won its votes as it argued that the integration of migrants and refugees was the biggest threat facing Europe.

Indeed, the leading AfD had been making extremist statements both before and during the 2017 election campaign (Dennison and Pardijs, 2016: 17). For example, the party's leader since September 2017, Alexander Gauland, has talked of fighting an 'invasion of foreigners' and declared that 'Islam is alien to German society'. During a post-election press conference, he claimed that 'One million people - foreigners - being brought into this country are taking away a piece of this country, and we as the AfD don't want that ... We say we don't want to lose Germany to an invasion of foreigners from a different culture'. Gauland has also remarked that 'Islam is not a religion like Catholicism or Protestantism. Intellectually, Islam is always linked to the overthrow of the state. Therefore, the Islamization of Germany poses a threat' (Kaya and Tecmen, 2019: 7).

Since it entered the parliament, the party has been using posters on every possible occasion against Muslims, who are generally dehumanized and portrayed as a foreign army of refugees invading Europe taking incentive to destroy its culture. For instance, the AfD's Bavaria branch opened their election campaign for the Autumn 2019 state elections with posters portraying white school children and advocating that schools should be 'Islamfrei' (free of Islam) (Jegić, 2018: 37). Indeed, AfD significantly increased its votes in the state election in Saxony in September 2019 with $31.9 \%$ to become the second party after the CDU. This shows that the party's anti-migrant and anti-Islam rhetoric was helping to increase its electoral support. Through the statements of its leaders and slogans it could be seen that AfD rested its votes on the differences between the German society and the incoming migrants and that this was seen as a threat. The cultural, ethnic, and religious otherness of these migrants, crucial to societal security, made migration securitized.

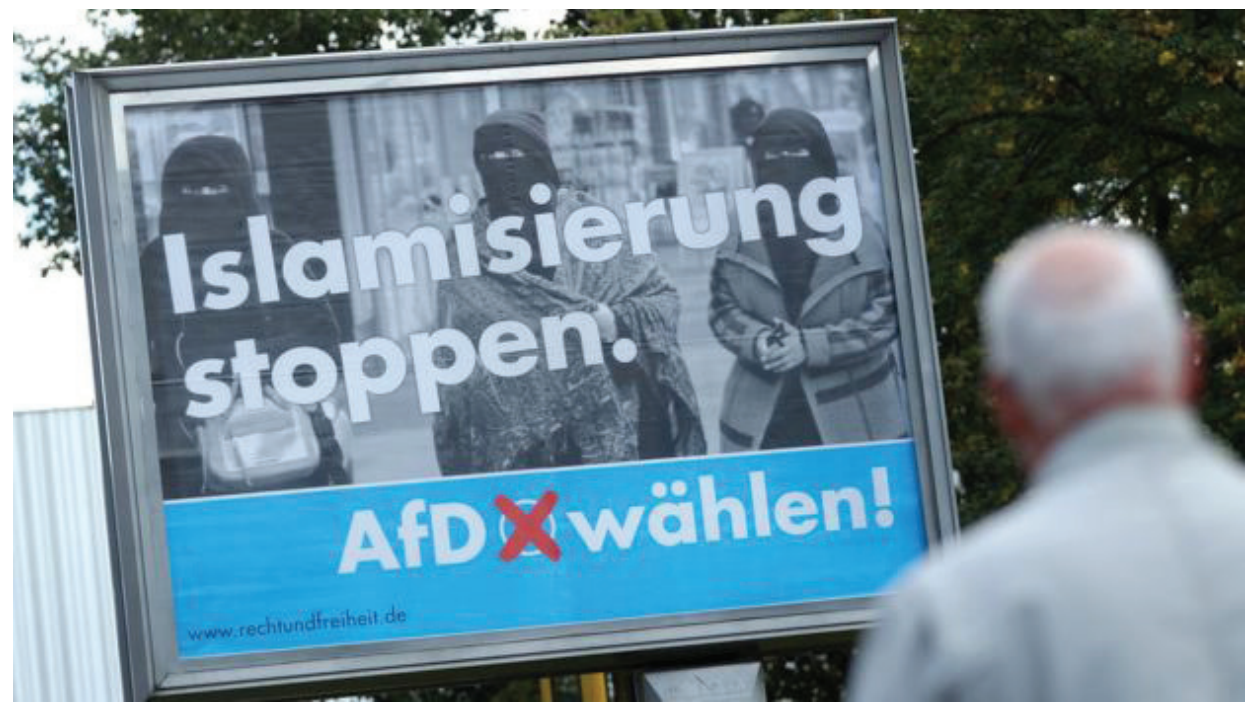


More parties in Europe securitized migration in their speeches and presented it as a security threat. In France, the Front National is the main political force opposing the 'quiet conquest' by Muslim migrants. Its growing electoral support made its leader, Marine Le Pen, one of the leading candidates in France's presidential elections. The United Kingdom Independence Party, with 17 percent of the vote, had its leader Nigel Farage (MEP) ferociously campaigning for Brexit as the only means of securing the UK's borders against the inflow of migrants, especially from other EU countries. In Italy, the Northern League (Lega Nord) preserved nearly 20 percent of the vote in the last elections. Its leader, Matteo Salvini, has a 33-percent approval rating, securing him a position as a rising political star.

\section{EU'S Securitization and Externalization of Migration Management}

The scholarly literature on securitization further introduced different approaches, namely 'practice' or 'tool' approaches. These have generally been represented through the policies of the EU in their writings. As already stated before, the representative of the French School of Security Studies, Didier Bigo, for example, developed an approach that refers to practices rather than discoursesin securitization research. Bigo(2002), emphasizes the importance of practices in such processes while the securitization done by practices reveals itself in the migration issue. However, his writings lack a precise definition of securitizing practices (Léonard, 2010: 235). Balzacq, on the other hand, adopts the tool approach by explaining the transformation of security tools into securitizing instruments (Balzacq, 2008: 78). He implies that securitizing practices can be defined in EU activities by conveying the idea that asylum-seekers and migrants poses a security threat to the EU (Léonard, 2010: 237).

For Balzacq, securitization theory does not need the assent of an identifiable audience. To understand this, the focus should be on the functions and implications of the policy instruments that are used to solve a public problem(Balzacq, 2008: 75). In his tool approach, the relationship between words and instruments is indeterminate. Instruments have 'latent developments' that generate unforeseen effects in most cases (Balzacq, 2008: 78).Securitizing tools are generally free from any accountability: most of the time, their existence is unquestioned while securitization instruments reconfigure public action. Here, the aim of a securitization instrument is to address issues identified as threats. Balzacq uses the concept of terrorism to show the implications of policy instruments. For him, the EU's policies on counterterrorism transform security tools into securitizing instruments. This change affects the politics and governing modes of EU counterterrorism. He gives the example of Eurodac (the EU asylum fingerprint database) and supports his argument by pointing out that the EU's counter-terrorism strategy creates a productive ground to widening Eurodac's scope (Balzacq, 2008: 80, 76, 88).

Regarding EU policies, migration today is a phenomenon to be securitized with the help of various tools and practices, such as data gathering, information sharing, and cooperation activities like enhanced training for border staff of member states. The EU is either widening the scope of some agencies or introducing new structures to securitize migration in their policies. We use the term 'symptoms' to explain the EU's tools and practices in five categories: Eurodac as a securitizing tool born out of the Dublin 
Convention; EU visa policy and readmission agreements; Frontex, with its tasks and operations; the hotspot approach; activation of the European Border and Coast Agency and return operations.

In 2013, the Common European Asylum System (CEAS) was introduced through several EU directives and the Dublin III Regulation. According to the latter, border countries are responsible for any asylum-seeker entering the Schengen area. However, this rule broke down completely after the wave of arrivals across European borders in 2015, when Hungary, Croatia, and Serbia took the drastic measure of erecting new fences along their borders. This shifted migration flows to neighboring countries, which closed the 'Balkan route 'and caused the deaths of thousands of migrants at Europe's external borders (Neimann and Zaun, 2018: 4). In 2016, the EU Commission responded by proposing an extension of Eurodac, which increases the securitization of migration. The proposal extends Eurodac's scope to irregularly staying third-country nationals by, for example, lowering the age of taking fingerprints to 6 years old, storing and comparing all three categories of data, and retaining fingerprint data for illegally staying third-country nationals or third-country nationals who have crossed an external border irregularly and who do not claim asylum for 5 years [Proposal for a Regulation of the European Parliament and of the Council COM (2016) 272 final]. According to the proposal, Eurodac will also use other biometric identifiers, such as facial recognition and the collection of digital photos, to counter the challenges faced by some member states[COM (2016) 272 final].The Commission defined the effect of this proposal as 'allowing Member States to track secondary movements and better identify people with no right to stay in the EU' in its Progress Report on the Implementation of the European Agenda on Migration [COM (2019) 126 final].

The coordination of visa policy and the coordination and facilitation of readmission agreements reflect the EU's internal and external policies whereby EU visa policy has already helped facilitate negotiations on readmission and the visa suspension mechanism. These can be considered as a symptom of the securitization of migration. Huysmans, for example, describes them as the restrictive and control-oriented imperatives that drive European migration policy. For him, the EU's restrictive migration policy indirectly supports expressions of welfare chauvinism while supporting the phenomena of cultural homogeneity as a stabilizing factor. This feeds into the politicization of immigrants, asylum-seekers, and refugees as an illegitimate presence and scapegoats (Huysmans, 2000: 770). Such a restriction can clearly be observed in Commission reports addressing the chain of migration management and its efforts to increase return rates to decrease the incentives for irregular migration and secondary movements. Here, one concrete tool is the readmission agreements signed with third countries to control the flow of irregular migrants. The 2019 report especially welcomes the agreement reached between the European Parliament and the Council on the reform of the Visa Code, while also referring the possibility of adopting restrictive visa measures against non-cooperative third countries on readmission [COM(2019) 126 final].

Some scholars have pointed out the reality of the politicization of migration and its presentation as a security threat, as instrumentalized in Frontex, the European Agency for the Management of Operational Cooperation at the External Borders of the Member 
States of the EU (Léonard, 2010: 232).Others describe Frontex as a logical continuation of integration and free movement doctrine of the EU. That is, it is not the outcome of securitization but rather a sign of its failure. However, for our analysis, we will focus on the first view (Neal, 2009: 344).

According to the first view, Frontex reflects the securitization of migration via its tasks. Starting with the joint operations task, it uses securitizing practices because they are generally operated by a team, including a group with semi-military status, which causes 'semi-militarization' of border controls, thereby securitizing migration flows. Joint operations are also securitizing practices due to their extraordinary character. The task of assistance training of national border guards reinforces the idea that the EU's external borders are under threat from irregular migration and need to be protected using sophisticated technological means(Léonard, 2010: 240, 241).In conducting its risk analysis task, Frontex often presents itself as an 'intelligence-driven organization'. The use of this concept rather than more neutral concepts, such as 'data' or 'information', contributes to securitizing asylum and migration in the EU. Lastly, the task of providing technical and operational assistance to EU member states when needed at external borders implies that migration flows can be so threatening that some countries cannot cope despite the existing cooperation mechanisms. This perception led EU member states to form regular RABIT training events (Léonard, 2010: 242, 244). The rationale is that the EU's external borders are facing continuous threat, as explained above. In temporary RABIT operations, such as Joint Operation RABIT 2010, the Greek Government asked Brussels to assist Greece in controlling its land border with Turkey for an 'exceptional mass inflow of irregular immigrants'. However, Operation RABIT 2010 was presented as evidence of effective 'European solidarity' (Carrera and Guild, 2010: 5).

The European Border and Coast Guard Agency (EBCGA) was activated in 2016to prevent irregular migration through border controls, fighting against human trafficking and smuggling. Compared with Frontex, this new Agency has improved sources, an enlarged mandate, and greater independence vis-à-vis Member States (Neimann and Zaun, 2018: 10). The EBCGA is also said to have more responsibility for contacting third countries. It can reach agreements with them to share expertise and assist on border management. As seen in the Progress Report on the Implementation of the European Agenda on Migration [COM (2018) 250 final], an agreement between the EBGCA and Albania was signed on 12 February 2018. This enables EBGCA to provide assistance in external border management and swiftly deploy teams on Albanian territory in case of a sudden shift in migratory flows [COM (2018) 250 final]. This enables more controloriented migration governance with third countries and expand the securitization of the migration issue beyond the EU's borders.

The hotspot approach is another symptom of the securitization of migration. The EU originally introduced this in response to the 2015 migration crisis. It aimed to support the Member States in question by deploying Migration Management Support Teams. Implemented first in Italy and Greece, the hotspot approach aims to provide organized and increased registration, identification, fingerprinting, debriefing, and return operations for asylum seekers (Neimann and Zaun, 2018: 5). The Support Teams should process asylum applications as quickly as possible. The work this approach presents, requires group study 
and coordination between Europol, Eurojust, Frontex, European Asylum Support Office, and the EU member state facing a migratory pressure at its borders $[\operatorname{COM}(2015) 240$ final].

Through detailed analysis of new approaches to the securitization of migration, it is inevitable to see an increased securitization of migration through EU policies and coordination mechanisms. The policies and tools explained above, has started to see refugees as a security threat that needs immediate action to be tackled on its borders. Added to the already analyzed Copenhagen school of securitisation we can say that EU migration and asylum policy is indeed formulated with a securitizing logic and when these policies are implemented, they serve to further the securitization of migration.

\section{Field Research Analysis}

\section{Method}

This section presents the analysis of in-depth interviews conducted with Syrians residing in Turkey. The primary aim of the interviews was to find out the participants' opinions and attitudes regarding the security discourse depicted by European countries and the EU's migration policies, and to observe their opinions and attitudes on the securitization of this issue. The interviews were conducted in areas with many Syrian residents, namely İstanbul (547,000 people), Gaziantep (441,000 people), and Hatay (428,000 people). Seven interviews were conducted in İstanbul on 14 December 2019, five were conducted in Gaziantep on 22 October, and six were conducted in Hatay on 21 October 2019, resulting in a total of eighteen interviews. Ten participants were females and eight were males, with heterogeneous education backgrounds, ranging from primary, associate, undergraduate, graduate, and doctorate degrees. Participants had come from various parts of Syria, including İdlib, Homs, Damascus, Cerablus, and Aleppo. They had lived in urban and rural areas of those residences. The interviews were conducted by the aid of an Arabic translator to ensure effective communication with the participants. However, based upon the language proficiencies of some participants, interviews were sometimes conducted in Turkish or English. ${ }^{3}$

The participants were all at least eighteen years old and residing in Turkey for the last three years. In the interviews, it is observed that the participants had started to generate a decent level of integration into Turkish society through language (basic level) and socialization. This influenced their perception of Europe and the securitization of migration.

Because of our specific focus on the securitization of migration, the interview questions were categorized to learn the participants' perceptions regarding this issue:

- Questions regarding attitudes towards migration to Europe

- Questions regarding securitization and welfare chauvinism

- Questions regarding securitization and cultural security perception

3 NGOs in Turkey, such as İmra Association and Shafak Organization, and experts from the Development Agencies of Gaziantep and Hatay, who work actively on migration and migrants, helped to find suitable contacts for immigration. 
- Questions regarding securitization and migrant's social security perception

- Questions regarding securitizing action and securitization tools

- Questions about leaders assumed to be 'securitization leaders' and the perception of their discourse

Regarding questions about the participants' migration attitudes to Europe, it was important to understand whether each participant's intention to reside in Turkey had a forced or voluntary basis. It was expected that participants would explain their case in terms of their own environment, namely relatives, friends, connections, networks,etc. The questions on securitization and welfare chauvinism were intended to uncover how these terms wereperceivedby migrants, particularly the idea of offering welfare services only to the citizens of EU member states (Mandac1 and Özerim, 2013:115). To analyze questions devoted to securitization and cultural security perception, tools which explore cultural assets including religion oriented, language oriented, customs oriented roots of European societies have been asked to participants in order to reveal their perception (Mandac1 and Özerim, 2013: 119).The questions on securitization and migrants' social security perceptions focused on social serenity in Europe and its relationship with migrants, along with the participants' opinions on the EU's role in defending migrant rights. The questions on securitization action and securitization tools asked for participants' perceptions of Frontex activities generated by Balzacq's securitization tool. This included questions to measure participants' attitudes towards EU policies and tools on visa policy or the EU Trust Fund. Finally, questions about the 'securitization actor' discourse, introduced by the Copenhagen School, aimed to uncover participants' perceptions about speeches given by senior EU officials and European leaders that particularly focused on immigrants.

\section{Major Findings and Analysis}

Participants in Gaziantep and Hatay highlighted the role of cultural security perception in preferring Turkey as a migration destination. For participants in İstanbul, however, the ease of finding a job was the major determining factor. Participants in Gaziantep and Hatay suggested that Turkey's Muslim culture, similar traditions, and proximity to Syria were all primary reasons for their migration decisions. Especially for participants with daughters, cultural and religious values and proximity were more important. In addition, participants generally did not wish to live in Europe because of their cultural security perception, specifically the risk of being seen as a threat in Europe because of their different religion and culture. This finding was very conspicuous. Because it showed the participants' own cultural threat perceptions. They were aware that if they had chosen to live in EU by maintaining their culture and religious values, they would not be comfortable because the homogeneous EU countries' citizens would see them as a threat. This threat perception was based on two sources: 1 . They had been following the headlines in several EU countries, especially Germany, France and Italy and were aware of the statements of populist politicians 2 . They had been hearing about the discomfort experienced by their relatives and friends who migrated to these countries. This perception was the same for all participants, including different educational backgrounds, as exemplified by the following statements: 


\section{Ibrahim (39), Academic}

"Actually, there was an opportunity to go to Germany. Especially my area of expertise is in high demand in Germany, so I had different opportunities. I have friends there too. However, I preferred to stay here. I prefer to reside in a Muslim country. I can say that the situation that we are in now is the same as the one in Syria in religious and cultural terms. I can feel the same as if I am residing in Aleppo. My friends in Europe have experienced anxiety because of hijab. ${ }^{4}$."

\section{Muhammed (30), Sales Representative}

"Here in Turkey, we feel just the same as if we are in Syria, but for our relatives living in Europe, it is different. They are having problems in finding halal food. They have daughters aged 12-13 and they are having problems when their daughters must wear a hijab. They are afraid that their children will adopt the traditions of Germans as we do not approve when a boy of 14-15 years old hangs out with girls and girls spend time with boys outside until late at night. I can understand why they think that way because we also applied to go to Germany and when the German government insisted that my mother and my wife should give pictures with their ears uncovered, we did not accept that and did not complete the application. And now my relatives feel excluded in Germany because they do not share the same religion, values and traditions with the Germans"

\section{Ahmed AbiMurabi, (30), Physical Therapist}

"Syrians living in Germany feel so different culturally that, instead of getting integrated into German society, they prefer to live with Turks in Germany, who are culturally and religiously closer."

\section{Muhammed (35), PhD in Finance}

"I don't want my children to grow up in a Western environment, so I prefer to stay in Turkey, go to a Gulf country, or go back to Syria. Cultural differences may only cause problems, so we do not want our children to grow up in the European culture. We want them to grow up in an Islamic culture. Germany, for example, might only be seen as a station: you get experience, certificates, formal documents, citizenship, and then continue your life. Culturally, it is very different for Syrians; I would not consider living there."

The chart below shows the distribution of answers to the question exploring the reasons for preferring to stay in Turkey instead of going to Europe.

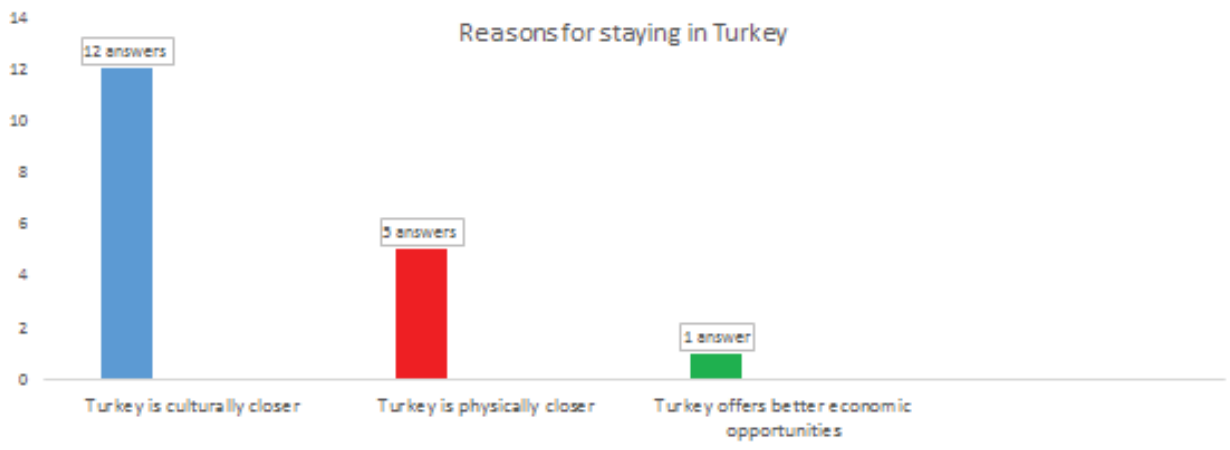

4 A hijab is a head scarf that some Muslim women wear in public. 
Regarding advantages, the participants listed several reasons as advantages of residing in Europe based on their perceptions of own relatives and friends already living there. They stated that Europe is very advantageous in terms of providing facilities to teach the host country's language, providing opportunities for migrants to continue their education, and/or finding a job. Once you are integrated, European countries do not differentiate regarding welfare distribution. In describing the life of their relatives residing in Europe, participants used the word 'comfortable', which often reflected the social welfare level. In addition, several participants mentioned personal freedom, through the sentence 'nobody interferes with the others'. In contrast, participants noted that these advantages were very limited in Turkey. For example, according to them, the Turkish government does not usually provide language lessons; it is very hard to get equivalency for diplomas received in Syria; and it is very difficult to find a good job.

\section{Usame (32), Sales Representative}

"When you go to Europe, you have time to learn the language. Here, however, it is more difficult. You must learn the language and work at the same time. There, they provide you certain conditions to learn the language for several years, and then you continue with the job that you desire. This is an advantage. I have a friend in Germany. He received a Google software certificate. He works in a big company. He had gone unofficially. Another friend of mine went to France officially. Now he works in the United Nations office."

\section{Zeynep (45), Law School Graduate}

"Most of our relatives who went to Europe are studying. Some are getting their bachelor's degree, and some are doing their master's. And they will stay there after they finish. This is good because we tend to have lots of children and Europe helps families who have been living there and have become already integrated."

\section{İbrahim (39), Academic}

"I already have a PhD from my university in Syria, so when I came to Turkey, I did not feel the need to try to go to Europe because I thought I would have similar conditions as I had in Syria because of my qualifications. But now I see that this is not the case. As it is getting more and more difficult each day here to find a decent job, I also started to think about trying my chance in Europe because I know that, especially in Germany, you have a chance if you want to further your studies or if you are already qualified."

Hiba (32, Housewife) supported İbrahim's arguments. Her brother, who is a mathematics teacher, could not find a job in Turkey. However, after moving to Germany, he learned German, found a job, started a master's degree, and took along his family as well.

Nevertheless, the question remains: Are these Syrians 'happy' in the host countries? Do they feel discrimination? According to Hilfa (35, Teacher), German Chancellor Angela Merkel in fact does not want any more Syrian refugees than the country needs. As Hilfa put it, "Syrians always leave their influence in society, so their culture and religion might become a distinctive feature in the host country and might be seen as a threat. I have read about Angela Merkel changing her positive attitude towards Syrian refugees after she suffered a loss in the elections in 2017 and lost many of her electorates' support to the racist party AfD. She had to pay attention to her electorates "perceptions." Ahmed Abu Arabi (27, Physiotherapist) had the same opinion. He distinguished between the public and the politicians. "Politicians are more pragmatic; they may see Syrians as a benefit for the economy, but the public is more emotional and they see refugees as threats, both to 
their economy and to their security, as they might be terrorists. That is why they started to vote for the racist parties."

\section{Semar (41), School Teacher}

"As you know, as they(Europeans) even care tremendously about animal rights. I believe they should care (more) for humans. To have radicalism is normal because it even exists in Turkey. For example, yesterday I was reading the comments on Facebook about a Syrian, and I found the comments very conservative. Eventually, the citizens of the host country believe that the refugees share benefits with them, and they are not happy about it. This dissatisfaction grows when these refugees are also different culturally and religiously. So, when the previous Italian prime minister, Silvio Berlusconi, refers to migrants as a 'tsunami', and I think this is an analogy made because of the tsunami's destructive effects on a country, I believe he is right."

The chart below shows the distribution of perceptions of Syrian settlers in Turkey about rising populism in Europe. This chart is important also to show the link between rising populism and the perception of migrants as a security threat.

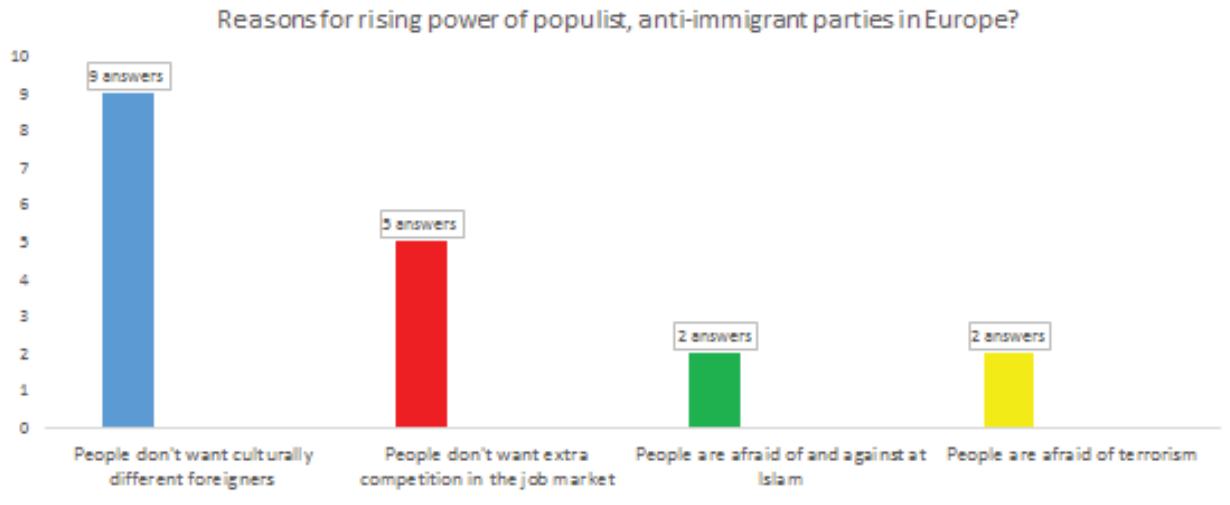

Despite the increasing perception of migrants and refugees as security threats, there are refugees living and working in Europe. The participants felt thatthose political preferences are involved when certain governments accept Syrians as refugees 'as Europe is ageing and there is a high need for qualified Syrians':

\section{Muhammed (35), PhD in Finance}

"Why is Germany accepting refugees? Because Germany needs the work force coming from immigrants. Sweden and Germany are attracting people for economic reasons. As you can see, they accept Syrians only according to their qualifications. I don't call that supporting human rights as advocated by Merkel many times. I call that the opportunism of a politician who wants to take advantage of hardworking Syrian people. They call themselves democratic and support democratic movements in other countries. I do not believe that. If they were democratic, they would be more insistent on helping Syrians get their democratic regime. Instead, they indirectly help Assad consolidate his power, which leads to more migration from Syria, and that leads to more qualified people for their labor needs. The rest can go back to Syria or back to Turkey."

5 An example of this can be seen in the German national elections in September 2017. As Merkel started to show her support for refugees, there was a reaction, especially in conservative parts of Germany, and increase in votes for a radical party, Alternative für Deutschland (Afd). 
Indeed, the statement of Muhammed regarding this issue was backed by a study of Federal Office for Migration and Refugees which found that almost 35 percent of refugees who had arrived in Germany in 2015 had a job by October 2018, compared with 20 percent the previous year. Herbert Bruecker of the Institute for Employment Research (IAB) commented on this finding as: "More than 50 percent of the refugees are working in skilled jobs, which usually require vocational training certificates or higher certificates. A combination of favorable labor market conditions, language programs and job placement initiatives are helping refugees land jobs. This flood of human capital is occurring at a crucial time for the economy in Germany with an aging population and low unemployment level. Since the 1970s, Germany's birth rate has declined quite dramatically, at the same time, average life expectancy has been going up. Without immigration, the potential number of workers in Germany would decline by $40 \%$ by 2060. With net immigration of about 400,000 people each year, we can keep this figure just about stable. (https://www.aljazeera.com/economy/2019/6/20/germany-welcomedrefugees-now-its-reaping-the-economic-benefits, https://www.dw.com/en/germanyneeds-immigrants-to-stay-competitive-economist/a-51158216)

While supporting the opportunism of Europeans mentioned by Muhammed, Ranim (33, Mechanical Institute Graduate) also noted the securitization of some migrants. As they are of 'no use' to the host country, they are considered a threat and lack the appropriate living conditions for human dignity.

"Germany currently takes advantage of youngsters and people with higher education. The life of uneducated people in Europe is harder. People who have low education have gone back to Aleppo because in Europe they lived in camps in harsh conditions; they lived in ghettos. They said, 'Instead of living under stress, I would like to reside in my own country and, if needed, I can die in my country."

The chart below shows the perceptions of Syrian settlers in Turkey regarding the attitude of Europeans towards migrants:

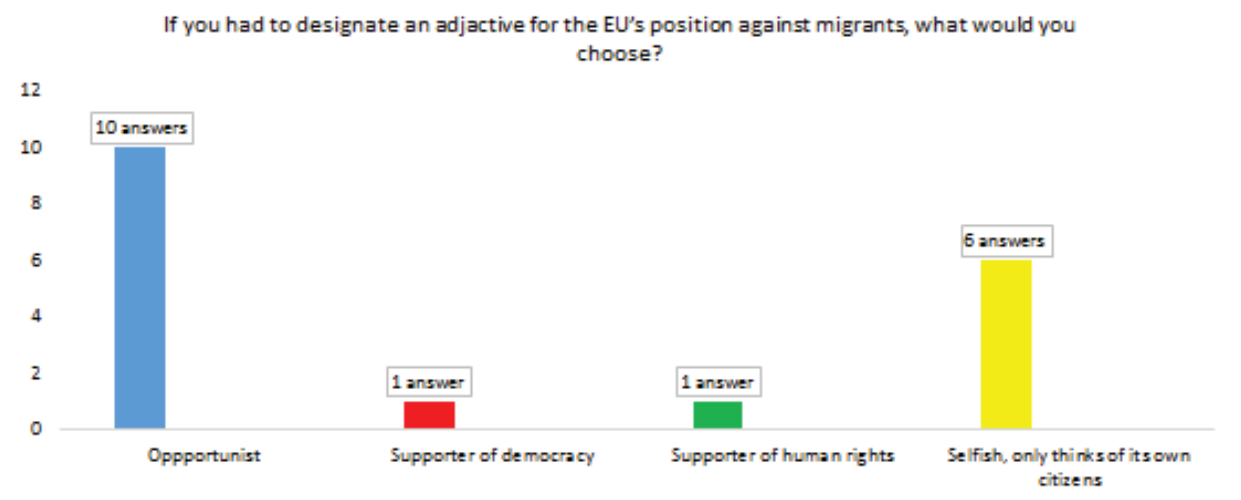

Thus, the perceptions of the participants we talked are of the opinion that while young and educated Syrians are seen as beneficial, low educated and older ones are seen as a threat. As the main reason why, the Syrians are fleeing to Europe is because of the serious human rights violations and threats to their life and well-being in their own country, this 


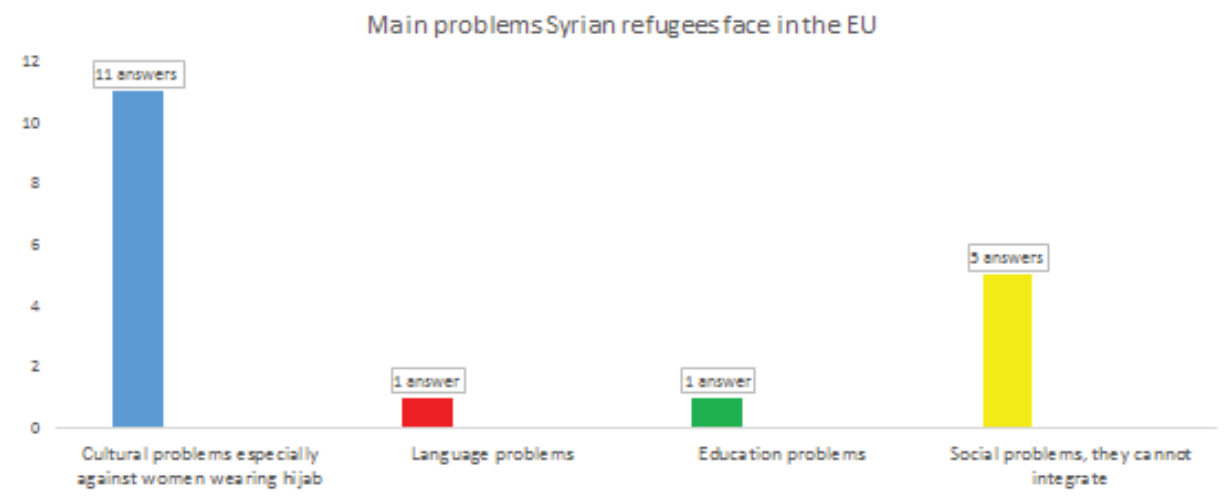

Íbrahim (39, Academic) explained why he lacked belief in Europe's democratic values.

"The road to democracy and the welfare of the Syrians will improve by finding the roots of the problems that led these people to migrate. These people had wanted democracy and human rights and were suppressed. Instead of hearing the Syrians' call for democracy, Europe is helping the reconstruction of some of the hospitals in Syria, which ultimately consolidates the current regime. How is that protecting democracy, human rights, and the security of people whose lives are in danger?"

Ruba(27) uses the phrase "protecting stability" in analyzing the EU's attitude towards refugees:

"For Europe, the stability of its own welfare is more important than democracy."

Although questions regarding the meaning, scope, and function of securitization tools of the EU were asked directly, the participants did not have enough information about them. For example, none of the participants have not heard any information about Frontex or the EU Trust Fund. However, even though they are not aware of these institutions, they predicted that those institutions function to protect Europe from terrorists or to prevent immigrants entering Europe. That is, they are institutions that support the security of EU borders and member state citizens.

\section{Conclusion}

As the EU's periphery becomes unstable, the EU has become more conscious about possible security threats emanating from its neighborhoods. This consciousness turned into more concrete actions as the EU was faced with an immense flow of refugees fleeing from chaos and instability in Syria. This ongoing threat to the welfare security community characteristics of the EU became the focus of both mainstream and radical parties' statements, manifestos, and politicians' speeches. Indeed, this new security threat was so relevant that it became the focus of populist parties, which started to increase their support from electorates who have become highly skeptical about incoming refugees. This reality was already explained by the securitization theory of the Copenhagen School, promoted by Ole Weaver, Barry Buzan, and Jaap de Wilde. Increasing migration not only influenced the statements and speeches of politicians as the EU also developed new policies and institutions to protect itself from these new risks. Thierry Balzacq and Didier Bigo offer a detailed analysis of these policies and institutions. 
In this study, we examined the perceptions of a sample of Syrian settlers living in Turkey. While the study drew mainly on securitization theory, it also considered analyses of policies and institutional practices. The participants clearly preferred to stay in Turkey, mainly due to their cultural and religious similarity with Turkish people. They had the perspective that they would have problems living in the EU as they would be seen as a threat by average citizens. They had been developing this perception of threat both through their exposure to statements of politicians found in traditional media and social media means and through realities of cultural and social insecurities experienced by their families and friends already living in Europe. They were also aware of the pragmatic reasons why European countries accept certain categories of refugees and migrants, namely the reality of an aging Europe in need of young, qualified people has pushed Europe's political leaders to make decisions regarding refugee applications.

In conclusion, we can acknowledge the increasing realism in the EU's attitude towards refugees. Although it was formed and promoted as a security community of shared values, the EU became a fortress when threats put at risk those values that comprise its security community. This creates an irony, however: those who apply to the EU as refugees and are rejected are seeking protection of their basic rights, such as the right to live and the right to live in safety and dignity - the very values that security community of the EU is made up of and that Europeans are proud of.

Peer-review: Externally peer-reviewed.

Conflict of Interest: The authors have no conflict of interest to declare.

Grant Support: The authors declared that this study has received no financial support.

Author Contributions: Conception/Design of study: Ö.Ü.E., P.S.; Data Acquisition: Ö.Ü.E., P.S.; Data Analysis/ Interpretation: Ö.Ü.E., P.S.; Drafting Manuscript: Ö.Ü.E., P.S.; Critical Revision of Manuscript Ö.Ü.E., P.S.; Final Approval and Accountability: Ö.Ü.E., P.S.

\section{References}

Adler, E., \& Barnett, M. (1998). Security Communities. Cambridge: Cambridge University Press.

Balzacq, T. (2008). The Policy tools of securitization: information exchange, EU foreign and interior policies. Journal of Common Market Studies, 46(1), 75-100.

Bartoszewicz, M. K. (2015). 50 Shades of radicalism: an analysis of contemporary radical parties in Europe. International Studies Interdisciplinary Political and Cultural Journal, 17(1), 27-41.

Bigo, D. (2002). Security and Immigration: Toward a Critique of the Governmentality of Uneasy. Alternatives, 27(1), 63-92.

Booth, K. (1999). Nuclearism, human rights and constructions of security, part 2. The International Journal of Human Rights, 3(3).

Booth, K. (2004). Realities of Security: Editor's Introduction. International Relations, 18(5).

Carrera, S., \& Guild, E. (2010). Joint operation RABIT 2010 FRONTEX assistance to Greece's border with Turkey: revealing the deficiencies of Europe's Dublin Asylum System. CEPS Paper in Liberty and Security in Europe.

Dennison, S., \& Pardijs, D. (2016). The world according to Europe's insurgent parties: Putin, migration, and people power. European Council on Foreign Relations.

European Commission. (2015). A European Agenda on Migration. Communication from TheCommission of the European Parliament, The European Council and The Council, The European Economic and Social Committee and The Committee of the Regions,240 Final, 13 May. Brussels.

European Commission. (2016). Proposal for a Regulation of the European Parliament and of the Council, 272 Final, 4 May. Brussels.

European Commission. (2018). Progress Report on The Implementation of the European Agenda on Migration. Communication from The Commission to the European Parliament, The European Council and The Council, 250 Final, 14 March. Brussels. 
European Commission. (2019). Progress Report on The Implementation of the European Agenda on Migration. Communication from the Commission to The European Parliament, The European Council and The Council, 126 Final, 6 March. Brussels.

Derrida, J. (1992). The Other Heading: Reflections on Today's Europe, Translated by Pascale Anne Brault and Michael B. Naas. Bloomington: Indiana University Press.

Deutsch, K. (1957). Political Community and the North Atlantic Area: International Organization in the Light of Historical Experience. Princeton University Press.

Deutsche W. (2019). Germany needs immigrants to stay competitive: economist.

Available at: www.dw.com/en/germany-needs-immigrants-to-stay-competitive-economist/a-51158216 (accessed: 1 December 2020).

Howell, A., \& Richter-Montpetit, M. (2020). Is securitization theory racist? Civilizationism, methodological whiteness, and anti-black thought in the Copenhagen School, Security Dialogue, 51(1), 3-22.

Huysmans, J. (1995). Migrants as a security problem: dangers of "securitizing" societal issues. In Migration and European Integration: The Dynamics of Inclusion and Exclusion, edited by Robert Miles and Dietrich Thraenhart, 53-72. London: Pinter.

Huysmans, J. (2000). The European Union and the securitization of migration. Journal of Common, Market Studies, 38(5), 751-77.

Ibryamova, N. (2002). Migration from Central and Eastern Europe and societal security in the European Union. Jean Monnet/Robert Schuman Paper Series, (2), 1.

Kaya, A., \& Tecmen, A. (2019). Europe versus Islam: Right-wing populist discourse and the construction of a civilizational identity. Review of Faith and International Affairs, 17(1), 49-64.

Killias, M. (2011). Immigration and crime: The European experience. Research Report Background paper EUUS Immigration Systems 2011/19.

Langwald, K. (2021). Multidisciplinary Approaches to Security: The Paris School and Ontological Security Available at https:/www.e-ir.info/2021/07/13/multidisciplinary-approaches-to-security-the-paris-schooland-ontological-security (accessed: 5 August 2021)

Léonard, S. (2010). EU border security and migration into the European Union: FRONTEX and securitisation through practices. European Security, 19(2), 231-254.

Mandacı, N., \& Özerim, G. (2013). Uluslararasıgöçlerinbirgüvenlikkonusunadönüşümü: Avrupa'daradikalsağpartilervegöçüngüvenlikleştirilmesi. Uluslararasillişkiler 10(39): 105-130.

Neal, W. A. (2009). Securitization and risk at the EU border: The origins of FRONTEX. Journal of Common Market Studies, 47(2), 333-356.

Neimann, A., \& Natascha, Z. (2018). EU refugee policies and politics in times of crisis: theoretical and empirical perspectives. Journal of Common Market Studies, 56(1), 3-22.

Stivachtis, Y. (2008). Civilization and international Society: The case of European Union expansion. Contemporary Politics, 14(1), 71-89.

Wouter, VDB.D'Amato, G.Ruedin, D. and Berkhout, J. (2015). The Politicisation of Migration. London: Routledge.

Waever, O. (1995). Securitization and Desecuritization. In: Lipschutz RD (eds) On Security. Columbia: Columbia University Press, pp.46-87.

Waever, O.Buzan, B. and Wilde, J.D. (1998).Security: A New Framework for Analysis. Boulder: Lynne Rienner Publishers. 
